\title{
"One Great Epic Unfolding": H.G. Wells and the Interwar Debate on the Teaching of History
}

\section{Ken Osborne}

\section{ABSTRACT}

This essay explores H.G. Wells's attempts to reform the teaching of history between the two World Wars. Holding history teachers largely responsible for creating the mood of bellicose nationalism that made the First World War possible, Wells concluded that only a fundamentally reformed history education would ensure the survival of the human species. He pressed for a global history, to be taught in all the world's schools, that began with the origins of the universe and ended with the present and a glimpse into the future that transcended national borders, and would be taught appropriately. Wells was widely read and often quoted by teachers but was unable to change the priorities of educational policy-makers. This essay examines his objections to conventional history; explores his alternative model of history education; and explains his eventual failure. Wells made an important contribution to the debate about history teaching in the inter-war years and his educational ideas have been unduly neglected.

\section{RÉSUMÉ}

Cet article expose les tentatives de l'écrivain H. G. Wells en vue de réformer l'enseignement de l'histoire entre les deux guerres mondiales. Il tenait les professeurs d'histoire responsables du climat de nationalisme belliqueux qui avait rendu possible la guerre de 1914-1918. Wells était arrivé à la conclusion que seule une réforme en profondeur de l'enseignement de l'histoire pouvait assurer la survivance de l'espèce humaine. Il préconisait une histoire universelle, enseignée dans toutes les écoles du monde, qui commencerait avec les origines de l'univers et qui se terminerait avec le présent et un aperçu du futur qui transcenderait les frontières nationales. Cette histoire se devait d'être enseignée adéquatement. Beaucoup lu et souvent cité par des enseignants, néanmoins Wells n'a pas réussi à influencer les orientations des programmes. Cet article examine sa critique de l'enseignement conventionnel de l'histoire, explore son modèle alternatif et explique son échec éventuel. La contribution importante de Wells au débat sur l'enseignement en histoire durant l'entre-deux-guerres et ses idées éducationnelles ont été par trop négligées.

\section{Introduction}

This essay examines H.G. Wells's attempts to reform the teaching of history in the years after the First World War - a subject that has been unduly ignored both by 
Wells scholars and by historians of education. It begins by locating Wells in the debates over history education that followed the ending of the First World War and explores his objections to the history that was taught in the schools of his day while also explaining why he saw history as such a crucially important subject of study. It then outlines his alternative model of history education in terms both of subjectmatter and pedagogy as evidenced by his admiration for a reforming school principal, F.W. Sanderson, to whose school he sent his own children. The essay ends with an assessment of Wells's failure to change the thinking of the educational policy-makers of his day.

Remembered today primarily for his science fiction rather than for his many other novels or his non-stop social commentary, H.G. Wells was also a would-be educational reformer who took a particular interest in the teaching of history. "Upon this matter of the teaching of history," he wrote in 1921, "I am a fanatic. I cannot think of an education as even half done until there has been a fairly sound review of the whole of the known past, from the beginnings of the geologic record up to our own time. Until that is done, the pupil has not been placed in the world. He is incapable of understanding his relationship to and his role in the scheme of things. He is whatever else he may have learnt, essentially an ignorant person." ${ }^{1}$ Viewed in this light, the history taught in schools conspicuously failed to measure up to Wells's standard. Studying what commonly passed as history in schools was so pointless, he maintained, that "If so many of us had not experienced it, few would believe it possible.... It is partly like heavy stale gossip about incredible individuals, partly like trying to get interested in the litigation of an unknown people in a remote country, and partly like watching a university don playing soldiers on his study floor." ${ }^{2}$

Even worse, the history taught in schools was not just a waste of valuable time; it was downright dangerous. As Wells wrote shortly before the beginning of the Second World War, "I believe that the crazy combative patriotism that plainly threatens to destroy civilization today is very largely begotten in ... school history lessons." $\mathrm{He}$ drew the obvious conclusion: "I think that the less young children have either in or out of school of what has hitherto figured as history, the better.... I suggest that the sooner we get that unpleasant stuff out of schools ... the nearer our world will be to a sane outlook upon life." 3 What was needed was a truly global history stripped of all national preoccupations, that treated homo sapiens as a whole, that began with the origins of the universe and proceeded up to the present while also stretching into a speculative future, all the while laying bare the "operating causes" (a favourite Wellsian phrase) that shaped the human journey. This kind of history, Wells insisted, would not only light up the classroom, it would change the world.

Today Wells the reformer of history teaching has been largely forgotten, even by educationists. Who now reads his explicitly educational novels, Joan and Peter (1918), The Undying Fire (1919), The Camford Visitation (1937), or his biography of a reform-minded school principal, The Story of a Great Schoolmaster (1924), not to mention his The Outline of History (1920), The New Teaching of History (1921), and the many essays he wrote in the inter-war years addressing educational themes? There is no mention of his work in the profusion of books and articles on the teaching of 
history and social studies that have appeared since his death in 1946, or in histories of education more generally. "There was a time," observed the Times Literary Supplement of London in 1946, "when Wells spoke more clearly than any other man to the youth of the world." 4 That time, however, seems to be long gone.

\section{The First World War and the Teaching of History}

It is universally recognized that the First World War was one of the most formative events of the twentieth century — "the seminal event of modern times," in the words of the historian David Fromkin. ${ }^{5}$ Less well known is the impact of the War on the teaching of history in schools in the 1920's and 1930's. In the 1920's, for example, there was general agreement that the eventual success of the newly created League of Nations would depend in large part on the creation of an internationally-minded and supportive public opinion. Canada's Prime Minister, Sir Robert Borden, spoke for many when he told the Versailles peace conference that the future of the League "would not depend upon the machinery that might be created, but on something behind it, namely public opinion, which would give it the power which steam or electricity gave to the machinery of a factory." And the seeds of this public opinion would be planted and nurtured in schools, and above all in history classes. In effect, the struggle to abolish war as an instrument of national policy and to create a universal spirit of "moral disarmament" was to begin in the history classroom.

For obvious reasons, once the Great War ended in 1918, all governments ensured that their schools impressed on students the extent of the sacrifice, suffering, and heroism of their armed forces. The curricular problem was to devote adequate classroom attention to the War and to recognize the heroism of the combatants, but without glorifying war as an instrument of national policy. To quote a British teacher, speaking in 1918, "The difficulty of teaching history to young people is particularly great at the present moment, through the efforts of the teacher to foster, animate, and intensify the true sort of patriotism, so magnificently displayed, while at the same time exorcising that false, unreflecting patriotism that can only think in terms of territorial expansion, and that is being fed by ignorant and boastful talk at the present time in some quarters; and this difficulty is linked up with the thought of internationalism." Part of the solution to this challenge was to portray the War as the war that would end war, to use a Wellsian phrase that was popular at the time, while also pointing to the League of Nations as the instrument of future peace. However, no government was willing to internationalize its history curriculum to the extent that Wells thought necessary. No government, and for that matter not the League of Nations, endorsed Wells's argument that what was needed was one supranational global history curriculum to be taught in all the world's schools alike. With the partial exception of those countries whose national ambitions were thwarted by the peace treaties and who felt unfairly treated by the League of Nations, schools for the most taught about the War in a pro-peace spirit, acknowledging the sacrifice of their citizens, but describing war itself as suicidally outmoded in an age when the world was becoming ever more interdependent and where military weapons were becoming ever more destructive. 
For many educationists the most compelling educational lesson of the War was the importance of a spirit of "service," both to one's nation and to one's fellowcitizens. This alone could justify the enormous losses of the War and the goal was to ensure that this spirit of service was not lost in the pursuit of peace-time pleasures. Seeking to bring coherence to a fragmented school curriculum while also giving the War some higher purpose, a British educationist insisted that "We can be content with nothing less than the word Service ... and our ideal will be expressed as the Personal and Collective Service of the Commonweal." ${ }^{8}$ Expressing a similar sentiment, the Canadian novelist and wartime military chaplain, Charles Gordon (aka Ralph Connor) observed in 1919, "I believe that here lies the solution of many of our present problems, that we should try to insert into our common everyday affairs that marvelous thing that held our men together on the front line-comradeship." For those in power an added advantage of this concept of service and comradeship was that it might also serve to create a barrier against the post-war upsurge of radical labour and socialist activity that in some forms took its inspiration from the 1917 Bolshevik Revolution and in others turned to a longer-standing anti-capitalist tradition. In the words of a 1925 Canadian royal commission, "From the viewpoint of self-preservation alone, society recognizes that the best form of state insurance against anarchy and bolshevism is an efficient system of public education." ${ }^{10}$ And, appropriately taught, history could serve to inoculate students against any inclination for left-wing politics. Though it lies beyond the scope of this essay, the post-war debate over history teaching featured a steady stream of left-wing opposition to what trades unionists and socialists (who sometimes turned to Wells-style history for inspiration) saw as the pro-capitalist class-bias of history texts and curricula.

Apart from deciding how the War might best be handled in the history classroom, history teachers in the inter-war years found themselves facing a variety of difficult questions. They all agreed that the War had demonstrated the need for students to have an informed understanding of the historical background to current events but there was much less agreement on what this meant in operational terms. How should they respond to those critics who claimed that the emphasis on national, and often nationalist, history in Europe's schools had helped create the climate of opinion that not only made the Great War possible but also turned it into the fight-to-the-death mass slaughter that it quickly became? What should be the proper balance between the teaching of national and of world history? Should history teaching be consciously directed towards the promotion of peace and the elimination of war and, if so, could this be done without turning history into propaganda, no matter how noble the cause? Was history best taught as a stand-alone subject or as part of an interdisciplinary social studies with an emphasis on the issues of the present rather than the achievements of the past? Was a version of social history better suited than a narrative of political events both to engage the interest of students and to prepare them for the responsibilities of citizenship? For that matter, what was, or should be, the connection between the teaching of history and the preparation of the young for citizenship and should that citizenship be defined in national or global terms? And if education for citizenship was the priority did that mean reducing the amount of time spent on 
ancient and medieval history in order to concentrate on more modern developments? Or was it better to teach history backwards, beginning with current events and then tracing them back in time? If history was to attain the ambitious goals proposed by its advocates, what kinds of teaching methods would be most effective? Whatever the answers to these and other questions, how could they be operationalized in the already overcrowded confines of the school curriculum, in which history was struggling to maintain its place? ${ }^{11}$

None of these questions was new but they were given added salience by the Great War which understandably raised questions of how the history curriculum, and indeed education more generally, should respond to the new conditions of the postwar world and help in the process of post-war reconstruction, a task that was seen as being intellectual and moral as well as physical. As a British educationist observed even while the War was still being fought: "A glance at the havoc caused in Serbia and Belgium, or at the graves of our dear British dead, is followed by the natural thought that we, like our Allies and our enemies, must rebuild; and one of the chief factors (why may not we say the chief factor?) in the process must be education." 12 The questions were given added force by the pressure of the League of Nations. With the creation of its International Committee on Intellectual Cooperation in 1922, its Institute for International Intellectual Cooperation in 1924-25, and its Subcommittee of Experts on League of Nations Teaching in 1926, the League of Nations took an active interest in the teaching of history in the schools of its member states. The League regularly asked governments to ensure that students were taught about its work and about international cooperation more generally, that more attention be given to social history, that much less time be spent teaching about war and conflict, that textbooks be scrutinized for undue bellicosity and bias, and that history curricula be organized around the theme of the growth of civilization, a process to which all nations and all classes made a contribution. A variety of international peace organizations made a similar case and regularly pressed history teachers to make the necessary adjustments in their teaching, while teachers' magazines and journals made frequent reference to the League of Nations and often quoted H.G. Wells, with his 1921 dictum that civilization was a race between education and catastrophe being a particular favorite. Thus it was that a prominent British historian, Alfred Zimmern, could note in 1930 that "one happy result of this movement for the teaching of the League of Nations in schools has been to lead to a reconsideration not only of the history programmes, but of the principles on which they are based." ${ }^{13}$ Zimmern was overstating the case but he had a point nonetheless: if nothing else, history teachers were aware that their subject was under scrutiny.

It is in this context of post-war debates over the teaching of history that Wells's campaign is best located. It had been almost a truism among Allied educationists during the War that the real enemy was not the German soldier but the German teacher who created the sense of discipline and commitment that they saw as underlying Germany's industrial and military strength. As Britain's Prime Minister Lloyd George put it towards the end of the War, "The most formidable institutions we had to fight in Germany were not the arsenals of Krupp, or the yards in which they turned out 
submarines, but the schools of Germany. They were our most formidable competitors in business and our most terrible opponents in war." ${ }^{14}$ It was a claim that raised an obvious question: if education was so effective as an instrument of war, why could it not similarly be used as an instrument of peace? To quote a British history teacher, speaking of his subject before an audience of colleagues considering "the effect of the War of the teaching of history," in 1918: "If, when wrongly taught, as in Germany, it could have such an admittedly evil effect, they could rest assured that there was a glorious heritage in store for their children if it could be rightly taught." ${ }^{15}$ The problem was, of course, to decide just what that right teaching should be. For Wells, a radically reformed history education organized along Wellsian lines, was the best, and perhaps the only, way to save humanity from future catastrophe.

\section{Wells as Educationist}

Trained as a science teacher, Wells took an interest in education from the beginnings of his public career in the 1890s. As he wrote in 1903, "Scolding the schoolmaster, gibing at the schoolmaster, guying, afflicting and exasperating the schoolmaster in every conceivable way, is an amusement so entirely congenial to my temperament that I do not for one moment propose to abandon it." ${ }^{16}$ However, it was the First World War that led him to single out the teaching of history as a matter of particular urgency. Always the rationalist, before 1914 he assumed that Europe's statesmen were too intelligent ever to resort to war and when, after 1914, he looked to historians for an explanation of what had gone wrong he discovered that they had nothing useful to tell him: "I did not know - and nobody else seemed to know - history in such a fashion as to be able to explain how the Great War came about or what ought to come out of it." ${ }^{17}$ When people looked to the history they had been taught in school they found only "an uninspiring and partially forgotten list of kings and presidents" all wrapped up in "nationalist blinkers, ignoring every country but their own and now they were turned out into a blaze." ${ }^{18}$ For their part, professional historians were unwilling, indeed unable, to venture beyond their narrow specialisms. In these circumstances, said Wells, he had little choice but to set about writing the new universal history that he saw as so urgently needed, primarily to shape public opinion but also to "demonstrate that there was some other method possible in history than that of sheer indiscriminate aggregation" of facts. ${ }^{19}$ The result was the publication in 1919-20 of his best-selling The Outline of History, setting out his vision of a new kind of history that embraced the totality of the human experience from its distant beginnings to the present: "Its background is unfathomable mystery, the riddle of the stars, the measurelessness of space and time. There appears life struggling towards consciousness ... through millions of years ... until it reaches the tragic confusions and perplexities of the world of to-day, so full of fear and yet so full of promise and opportunity" and always conveying the message: 'This is our inheritance. ${ }^{20}$

Wells concluded that the War was only in part the result of diplomatic miscalculations and military mistakes; equally, and perhaps more, influential were habits of mind that were rooted in the past, reinforced by people's ignorance of the full sweep 
of human history going back to the beginnings of life on earth. He began the War as a patriotic champion of the Allied cause though for him the enemy was the German political regime of "Kruppism and Kaiserism" and not the German people as a whole. At the same time, he saw the War as providing an opportunity to build what he saw as a saner world, if only people had the sense to seize it. By 1916, as described in his semi-autobiographical novel Mr. Britling Sees It Through, disillusionment had begun to set in and Wells became active in the movement to prevent any future war through the creation of a truly effective League of Nations. By the end of the War he had concluded that it was the "poison called history" taught in the world's schools that was largely at fault. It not only narrowed people's horizons and persuaded them that it was their patriotic duty to kill and if necessary die for their various countries but also failed to provide any key to understanding the present and thus shaping the future. ${ }^{21}$ In effect, history teachers were ultimately responsible for the War. Thus, the crucial task was to lay out a new direction for history education. Apart from any moral considerations, modern weaponry had made war too destructive to serve as a rational instrument of national policy and, to use a phrase first coined by Wells, the Great War must somehow be the war that would end war. ${ }^{22}$

For the most part, Wells by-passed the professional educationists' debates which he saw as unduly preoccupied with the details of pedagogy and he came to mock his "pathetic disposition throughout a large part of his life to follow schoolmasters about and ask them to be more so, but different" (though, referring to his early days as a school-teacher, he also noted that he was "so much an educator that quite early he found it imperative to abandon school-mastership.") ${ }^{23}$ More fundamentally, he came to see schools, not as an instrument of change, but as "a conservative force in the community ... controlled by authority and bound officially as well as practically to respect current fears and prejudices." ${ }^{24}$ In Well's 1891 novel, The Wonderful Visit, the "philosophical tramp" explained the purpose of a village school to a visiting angel: "They take 'em young into that school, and they says to them 'come in 'ere and we'll improve your minds,' they says, and in the little kiddies go as good as gold. And they begins shovin' it into them. Bit by bit and 'ard and dry, shovin' out the nice juicy brains. Dates and lists and things. Out they comes, no brains in their 'eads, and wound up nice and tight, ready to touch their 'ats to anyone who looks at them." Teachers, said the tramp, were like taxidermists: "They takes a frog and they cuts his brains out and they shoves a bit of pith in the place of 'em. That's a pithed frog. Well — that there village is full of pithed human beings.... Every one of them 'as 'ad their brains cut out and chunks of rotten touchwood put in the place of it." As for the school, "That's where they piths 'em."

In these circumstances, Wells decided that the best way to bring about the changes that he saw as so desperately needed was not to work within the school system (though he never gave up trying to persuade teachers of the errors of their ways) but rather to mount a many-sided campaign to mould public opinion and thus reshape schools from the outside: "But though here the government may be helpful, and there dark and hostile, the essential task of men of good-will in all states and countries remains the same, it is an educational task, and its very essence is to bring to the minds of all 
men everywhere, as a new basis for world co-operation, a new telling and interpretation, a common interpretation, of history." 26 As Wells wrote in 1921, "The teacher, whether mother, priest, or schoolmaster, is the real maker of history; rulers, statesmen and soldiers do but work out the possibilities of co-operation or conflict the teacher creates...." 27

According to one recent biographer, Wells's best-selling The Outline of History "created a small revolution in the teaching of history." ${ }^{28}$ This is far too optimistic an assessment, however. Wells certainly hoped the Outline would serve as the basis of a reformed history teaching in the world's schools but concluded in 1934 that though "the professional teachers of history" could not stop the public from reading it, they were "much more successful in keeping it out of the schools," where "King and Country and Period still prevail and it is just a matter of luck whether or not an intelligent boy or girl ever comes to the newer rendering of historical fact" embodied in his Outline. ${ }^{29}$ A 1926 American text on the teaching of history used Wells's phrase "the mind of the race" and spoke of history as the history of civilization, which was very much a Wellsian idea. However, it went on to argue that the study of world history must be accompanied by the study of American history, thereby vitiating the force of Wells's insistence that all national history should be scrapped unconditionally and replaced by a truly cosmopolitan history of humanity as one interconnected species. ${ }^{30}$ Such was the fate of Wells's educational arguments generally: when they were not simply ignored, dismissed as impractically utopian, or condemned as rigidly doctrinaire, they were domesticated and de-radicalized. Twenty years after the publication of his The Outline of History he was still lambasting history teachers for "teaching history in the wrong way and in the wrong spirit" and insisting that "a far more drastic revision of our ideas and methods" was needed than most teachers were disposed to support. ${ }^{31}$ According to one commentator, the Outline was "virtually ignored by the educational world but widely read by the general public." ${ }^{2}$ However, as Wells himself acknowledged, of the more than one million copies of his Outline of History that were sold, admittedly in many cases in the form of book-club special offers, only "two or three thousand were ever attentively read." The rest were simply "bought and stored away." 33 Describing his 1939 lecture tour in Australia, Wells noted that "Everybody was very nice to me and said I was extremely stimulating, but I did not perceive any evidence of stimulation.... At Canberra they said they found my last paper very stimulating, very stimulating indeed ... and then, very hastily, before I could say any more, they began to talk of other things." 34

Not surprisingly, Wells's root and branch rejection of national history went too far for national curriculum planners. He favoured a truly global history that transcended national borders; they would go no further than endorsing what one Canadian jurisdiction called a "healthy nationalism and a reasonable internationalism" and so fell far short of what Wells saw as so urgently needed if civilization was to be saved and catastrophe avoided. ${ }^{35}$ Aside from requiring history teachers to teach a few lessons on the League of Nations and acknowledging the interdependence (a favorite word of educationists in the inter-war years) of nations in the modern world, no national ministry of education was likely to endorse Wells's scathing indictment of 
nationalism and even patriotism. "To me," he wrote, "they are base, cramping, crippling, unjust, falsifying and altogether mischievous and degrading forms into which human minds are compressed. They produce what may prove to be an impossible jungle of intellectual difficulties on the way to the world state and a rationalized conduct of human affairs." 36 Nor was he any more sympathetic to the concept of internationalism which he saw as falling far short of the supranational cosmopolitanism that the world so badly needed. He condemned the League of Nations as merely a "squirming heap of patriotisms" where national governments played old-style power politics under a new name. ${ }^{37} \mathrm{He}$ also dismissed the League's International Committee on Intellectual Cooperation, which handled the League's educational programmes, as "obscure and ineffective" and sardonically admitted that his critics were right to say that he did not know much about it but only because the Committee had achieved so little that there was "very little to be known." 38

For Wells the key to successful reform was to be found neither in anything the League of Nations did nor in the predictably half-hearted efforts of national ministries of education. In his view only teachers, inspired by a Wellsian vision of education and urged on by a supportive public opinion, could bring about the kind of reforms he desired. In Wells's view there were two intertwined explanations for what had caused the First World War and might well produce a second and they both could be traced back to the malign influence of history teachers. They were, first, what he called the "foreign office thinking" or "great power thinking" of the policymakers and, second, the belligerently patriotic enthusiasms that led people to support their governments' policies in times of crisis, no matter how mistakenly self-defeating they proved to be. In both cases, the state of affairs they revealed could be corrected only through a better understanding of history and a new approach to teaching it.

In his dismissal of "foreign office thinking" Wells dissected what he saw as the errors of national policy-makers: "People of this class are caught young before any power of defensive criticism has developed in them and told stories of a series of mythical beings, France, Germany, England, Spain, with such assurance that they become more real than daddy and mummy." ${ }^{39}$ The result was that national policymakers saw their most important task as the pursuit of the chimera called the national interest. They were governed by the "marshalled misconceptions of the past" and "few so formed ever come round to a sane scepticism about these foolish simplifications." ${ }^{40}$ Unfortunately, at least from Wells's point of view, foreign office thinking had a hold on men and women at all levels of society: "Nationalism is the purest artificiality, and is made by the teaching of history and by nothing else; history taught by parents, friends, flags, ceremonies, as well as by the persistent pressure of schools, but mainly in the schools. And by this man-made nationalism the very existence of civilization is threatened." ${ }^{11}$ To Wells the solution to this state of affairs was obvious: "Once a modernized education has cleared up the human mind in this matter, such widespread delusions will be inconceivable." ${ }^{42}$ And in this task history teachers had a crucial role to play. Writing to a friend in 1919 he noted that "I feel more \& more that we cannot get on much further until people's historical ideas are cleared up." ${ }^{33}$

It was an obsession that after the First World War was never to leave him. As he 
wrote in his autobiography, "The idea of doing all I could for the reconstruction of the content of education became so dominant with me that it ruled my intellectual life and shaped my activities for some years.... In some manner the new education had to be got into the education office and the syllabuses of the schools, and since noone else seemed to be doing it, I felt under an obligation to try, however ineffectively, to do something about it myself." ${ }^{44}$ Above all, this meant transforming the teaching of history: "For the new times there was needed a new teaching of history, the history of man's rise and achievement as one story; history could be treated no longer as a national rather than as a universal subject...." ${ }^{35}$ He claimed no originality in making this argument, observing that the American pioneers of the "new history" of the early 1900s, James Harvey Robinson and James Breasted, two of the few professional historians for whom he had any respect (a third was the University of London's Eileen Power), had been there before him, and acknowledging his debt to Winwood Reade's The Martyrdom of Man, a favourite of free-thinkers and rationalists that had first appeared in $1872 .{ }^{46}$

A committed Darwinian, Wells saw the message of history and the message of nature as one and the same, adapt or die: "Mental and moral adaptation is lagging dreadfully behind the change in our conditions. A great and menacing gulf opens which only an immense expansion of teaching and instruction can fill." ${ }^{47}$ The problem with patriotism and nationalism was that they were mal-adapted to the changed environment in which, thanks largely to the new technologies of transportation and communication, together with increasingly supranational patterns of trade and investment and ever more destructive weaponry, national obsessions were becoming increasingly irrelevant. What made this especially frustrating for Wells was that men and women seemed to have lost the supreme adaptability that they had demonstrated throughout their history. In Wells's satirical critique of British universities the extraterrestrial visitor tells Camford's "Professsor of Latent History" that he had been following earth's progress for millions of years: "Always so far your interesting little species has met almost every challenge Nature has given it. Its adaptabilities have been enormous. But now. It seems to be trying to sit down just when it ought to be learning and adapting harder than ever. What is the matter? Are those bony little skulls of yours getting too tight? Full up? Pot bound?" ${ }^{48}$

Wells's answer to this question was that people failed to understand their own history. Until they did, further advance was impossible. "I have never thought, much less have I asserted," he wrote in 1940, "that progress was inevitable, though numerous people chose to fancy that about me. I have always maintained that by strenuous effort mankind might defeat the impartial destructiveness of nature. I have always insisted that only by incessant hard-thinking and a better co-ordination of man's immense but dispersed powers of self-sacrifice and heroism was such victory possible." ${ }^{49}$ And this much needed hard-thinking had to be founded on a new supranational conception of human history. For Wells change was urgently needed, not simply to prevent otherwise inevitable disaster, but to lay the foundation for a new and attainable age of peace and plenty: "There is a hitherto undreamt of fullness, freedom and happiness within reach of our species... But if mankind fails to apprehend its 
opportunity, then division, cruelties, delusions and ultimate destruction lies before our kind." ${ }^{50} \mathrm{He}$ compared contemporary society to an aeroplane powered by an unreliable engine which was "popping and showing many signs of distress. It may win to an aerodrome and repairs and replacements. Or it may make a very unpleasant forced landing presently with very little hope of immediate recovery." 51 And among those necessary repairs and replacements, a reformed history teaching would play a leading role.

This reformed history education must include the story of the development and impact of science and technology as an important part of its narrative. Wells observed in 1942 that "From my very earliest book to the present time I have been reiterating that unless mankind adapted its social and political institutions to the changes invention and discovery were bringing about, mankind would be destroyed." ${ }^{2}$. The history of coal and iron, to take only one example, made "the little strutting figures of Alexander and Napoleon, and the silly things they said and did, very small indeed to me." ${ }_{53}$ At the same time, a Wellsian analysis of history showed that "from earliest times man appears in biological history as a nuisance to himself as well as to the rest of living things...." 54 Like a modern-day environmentalist, Wells decried the accelerating destruction of the world's forests, the despoliation of farmland, the depletion of mineral resources, and the disappearance of many species of plants and animals, all of which he blamed on governments' pursuit of erroneous conceptions of so-called national interest, bolstered by the suicidal energies of undirected global capitalism. "Quite apart from war," he wrote in 1940, "our planet is being wasted and disorganized. Yet the process goes on without any general control, more monstrously destructive even than the continually enhanced terrors of modern warfare." 55 Here again, conventional history teaching had failed. It did "nothing ... to awaken the minds of the coming generation to the supreme gravity of this process." 56

Wells saw only one way out of the crises facing humanity, be they political, technological, or environmental: the creation of a world state based on a new sense of global identity shared by all the world's people and rooted in a supranational historical consciousness that he called "the mind of the race" (meaning the human race as one undivided whole). He made it abundantly clear that he was not speaking of a world state in any conventional sense. Governments were the problem, not the solution. To the extent that education was truly effective, it would make government redundant. As the Utopians told their earthling visitors in Wells's 1923 fantasy, Men like Gods: "There is no rule nor government needed by adult Utopians because all the rules and government they need they have had in childhood and youth.... Our education is our government." ${ }^{57}$ In this spirit, Wells denied that the world needed a global Caesar or even a global Buddha or Aristotle: "There will never be a World State, as we apprehend a State. As the new methods get into working order the national governments will vanish, softly and unobtrusively, from the lay-out of the world." 58 To make his point, Wells offered the Universal Postal Union as an example of what he had in mind. It did not seek to control people as governments did. It simply met a need and went about its business: "And the only force behind it to keep it working well is the conscious common sense of mankind." ${ }^{59}$ It is obviously a very superficial analysis that 
ignores the reality that the Postal Union worked only because there were national governments that approved its decisions and ensured that they were implemented. But it illustrates Wells's problem: how to construct a world state that was not in fact a state at all in any conventional sense of the word. The political reality was that the only viable path to a Wellsian world state lay through the tangled thickets of national governments, but, rather than working with them, Wells opted to go around them and so condemned himself to failure. In the words of one contemporary, "He could educate and impel, but could not himself organize, command or direct" — though it would be more accurate to say, not that he could not organize and direct, but that he chose not to. ${ }^{60}$

To make his world state possible, Wells argued, it was more fundamental to effect a transformation in people's thinking than to tinker with merely institutional reforms. Once people saw themselves as members of one interconnected species living on a finite planet, then some kind of world state would automatically follow, not as the result of some revolutionary cataclysm but as a process of evolutionary development, guided by a Wellsian understanding of history: "It will not be set up like a pavilion, but it will grow like a tree." ${ }^{61}$ All of which brings us back to education. Teachers faced an "immense task ... and that is the task of building up a new spirit in the hearts of men and a new dream in their minds, the spirit of fellowship to all men, the dream of a great world released forever from the obsession of warfare and international struggle; a great world of steadily developing unity, in which all races and kinds of men will be free to make their distinctive contributions to the gathering achievements of the race." 62

At first glance there might seem to be some similarity between the tenets of anarchism and Wells's vision of an ideal future society free of government but he disavowed any such direct linkage. His 1923 fantasy, Men like Gods, described a quasianarchist utopia but Wells did not see anarchism as offering anything that could be of use in the real world of actually existing institutions and habits of mind. He had no time for the violence of the "propaganda of the deed" version of anarchist protest and saw the more philosophical versions of anarchist theory as impossible of attainment. For Wells, philosophical anarchism was an idealized expression of the "constructive" (and distinctively Wellsian) socialism that he himself espoused and that led him, more or less reluctantly, to support the British Labour Party, even running unsuccessfully as Labour candidate for the University of London seat in two parliamentary elections in 1922-23. Viewed in the long term, socialism was "the schoolroom of true and noble Anarchism." ${ }^{63}$ In the short term, the problem was that the attainment of Anarchist ideals demanded more of people that they could ever achieve, at least until their education was radically reformed. Too many would-be anarchists, Wells wrote in 1907, were "temperamentally adverse to the toil, to the vexatious rebuffs, and insufficiencies, the dusty effort, fatigue, and friction of the practical pursuit of a complex ideal." 64

From time to time, but never more than very briefly, Wells considered the creation of a group of elite leaders who would put humanity on a new path. In his A Modern Utopia of 1905, consciously following the example of Plato's guardians, he pondered 
the formation of modern "samurai." In the early 1920s he was briefly intrigued by the political vanguardism of Lenin's Bolsheviks and Mussolini’s Fascists, though never by their ideologies, which he condemned as historically false and politically abhorrent,. In the 1930's he briefly mused about the possibilities of a liberal fascism. This said, however, he always ended up rejecting any kind of political or ideological dictatorship, writing in 1938 that "We do not want dictators, we do not want oligarchic parties or class rule. We want a widespread world intelligence conscious of itself." 65 Wells saw his best hope as the emergence, created by education, of "an informal, unselfish, unauthorized body of workers, a real and conscious apparatus of educational and moral suggestion, held together by a common faith and a common sentiment and shaping the minds and acts and destinies of men." ${ }^{66}$ By the 1930s this idea had taken more definite shape in the form of the "open conspiracy," a loose aggregation of individuals and groups all driven by the same impulse and shaped by the same education and working informally in their various spheres of life to bring about the global consciousness that alone could prevent disaster, but never taking a single institutionalized form. "With the dreadful examples of Christianity and Communism before us," he warned, "we must insist that the idea of the Open Conspiracy ever becoming a single organization must be dismissed from the mind." ${ }^{\prime \prime}$ This open conspiracy would be both the product and the promoter of a Wellsian education, and above all of the reformed history teaching that he saw as so necessary if humanity was to seize the future.

In turning to history to produce the kind of new thinking he saw as so important, Wells distinguished between history as an academic discipline and history as a subject to be taught in schools. There was, he insisted, a basic difference between "study for knowledge," which was legitimately the province of academic historians and researchers, and "the general education of the citizen." ${ }^{68}$ To ignore this distinction meant that history in schools would be only a boiled down version of history as taught in universities, suitably simplified for school-age children and minimally trained teachers and becoming as a result nothing more than "an affair of dated events, a record of certain wars and battles, and legislative and social matters quite beyond the scope of a child's experience and imagination," so that it became little more than an "arid misuse of memory," saying nothing about the world in which children were growing up, teaching them nothing useful about the past, and failing utterly to prepare them for the future ${ }^{69}$ According to Wells, too many history teachers - even among that small minority who thought about such issues - saw themselves more as historians than as teachers when what was needed was not "historians who teach" but "teachers of history who are teachers whose instrument is history." One sees his point but it is not clear why he ignored the seemingly obvious reality that to teach history satisfactorily at any level of education requires that teachers have some understanding of history as a form of disciplined inquiry. Though Wells failed to address the question, disciplinary history and teachable history are not mutually opposed but symbiotic. Nonetheless, he was making a point that sometimes seems at risk of being overlooked in today's concentration on the teaching of historical thinking: history, and especially the history taught in schools, must serve 
some educationally useful, and ethically defensible, purpose that goes beyond the acquisition of purely disciplinary skills and insights.

As Wells saw it, the history teacher's most pressing task was to take students "out of themselves ... to make them realize themselves as actors and actresses in a great drama which began long before they were born and which opens out to issues far transcending any personal ends in their interest and importance." ${ }^{71}$ To achieve this, history teachers needed not a detailed knowledge of some particular historical period or an immersion in the professional skills of the historian but rather an understanding of the whole sweep of history from the very beginnings of the universe to the present day. Without this knowledge, both teachers and students were condemned to helplessness. In the words of the extraterrestrial Visitor to Camford University, "I have seen life clambering out of drifting slime towards consciousness and will. I have watched the ascent of your species to the dawn of understanding and the beginnings of power." But now the Visitor was growing impatient, "For I see plainly that I overrated your intelligence, that you have blundered into knowledge and opportunity, and that you do not know how to grasp your knowledge nor how to realize your opportunities.... You realize neither the dangers nor the possibilities of human life."72 And without a Wellsian understanding of history, this realization would never become reality.

For Wells human history was only the latest chapter in a continuing evolutionary story, a story of human beings seeking to adapt to and master their environment on the basis of scientific knowledge, rational thought, and cooperative action. The story-line was the replacement of the hierarchical, tradition-bound "community of obedience" by the rational and democratic "community of will." When criticized for imposing a preconceived ideological pattern upon the past, Wells denied the charge and replied: "I set about collecting what is known of life and the world in time and space, and I find the broad outline falls steadily and persistently into a story of life appearing and increasing in range, power, and co-operative unity of activity." 73

His reviewers were quick to spot his tone. The American historian, Carl Becker, observed that Wells conveyed "the impression of telling us less about Dame History than about what is 'the trouble' with her; he lectures the perverse old lady, checks up her faults, notes her stupidities, and exposes all her worst blunders as if he took a warm paternal interest in the mending of her ways." ${ }^{\prime 4}$ As a Canadian teacher put it in 1926, "Mr. H.G. Wells is furious with the Greeks and Romans for not inventing printing - they came so near to it and yet missed." 75 A British historian accused him of indulging in "the disdain and fury of a berserker" in his condemnations of those individuals and societies in the past who failed to act as he thought they should have acted. $^{76}$

Such assessments, however, do not do justice to Wells's approach to the past. He certainly pointed to places where history could have taken a turn for the better but failed to do so but he was well aware that it was unhistorical to criticize the people of the past for not entertaining thoughts that could not possibly have occurred to them. In the case of Alexander the Great, for example, he cautioned that before "We ascribe to Alexander or to his father Philip schemes of world policy such as a twentieth century historian-philosopher might approve, we shall do well to consider very carefully 
the utmost range of knowledge and thought that was possible in those days." then had only a very narrow knowledge of history and geography. The social sciences were a closed book to them and natural science was in its infancy. As a result their outlook on the world was inevitably restricted when viewed by modern standards and it was the historian's task to see the world as they saw it not to chastise them for their short-sightedness.

In passages such as this Wells was demonstrating that history was more a matter of exploring questions than it was of establishing once-for-all answers. Indeed, the early editions of The Outline of History contained footnotes describing the objections of his academic advisers to some of the claims he was making (they were dropped from the 1926 and subsequent editions), thereby illustrating the interpretative nature of history. Moreover, Wells incorporated interpretative issues directly into his narrative. In the case of Alexander the Great, for example, he noted that "the opinions men have formed of Alexander himself vary enormously." Scholarly opinion could be divided into two camps. "One type of scholar is fascinated by the youth and splendour of this young man" and took him at his own valuation, excusing his crimes and vices as mere indiscretions, and treating his career as "framed upon a design, a scheme of statesmanship, such as all the wider knowledge and wider ideas of these later times barely suffice to bring into the scope of our understanding." On the other hand, there were those who saw Alexander "only as a wrecker of the slowly maturing possibilities of a free and tranquil Hellenized world."78 And having laid out the options, and stated his opinion, Wells left his readers to make up their own minds.

In short, Wellsian history was not the definitive record of a dead past, but an introduction to a living present and, as such, a matter of continuing debate. He expected his readers to challenge his arguments; what mattered was that they would come to appreciate the importance of history and think deeply about the meaning of the whole of the human past. As he noted in the 1926 edition of The Outline, there would never be an outline of history that was not "tendential" and he wrote within "his own limitations and the limitations of his time," while the Outline he would most like to read was the edition which might appear in 2026 . $^{79}$

Despite his apparent didacticism, Wells would have been no enemy to the concepts of historical thinking or historical literacy so much emphasized by today's history educators, though he would no doubt have insisted that they must never be treated as ends in themselves. What he wrote of science teaching applied also to history: "Far more important than scientific knowledge is scientific method." ${ }^{80}$ In fact, in a Wellsian education a key goal of teaching in all subjects was "learning to think," to learn to use language "like a rapier," to learn "the exact and rigid reasoning processes of mathematics ... and the methods of the science investigator," and all this, "not for the sake of knowledge but as mental exercise." Discussion of theories and generalizations was more important than "the accumulation of facts." At the same time, however, teachers had to remember that all this was "merely equipment and the sharpening of the human instrument." It was a necessary foundation for the "establishment of a persona which will lead to the service of the race and protect the individual from social mischief, economic offenses, political delusions, frustrations, 
disappointments and evil conduct towards others." Thus "a picture of the world" had to be "imposed upon the growing mind. The foundations of its ideology have to be laid." In short, disciplinary skills and competencies were essential but so were knowledge and understanding.

Between the Wars The Outline of History became the basis for three short books written by Wellsian disciples and designed for school use but intended only to supplement existing textbooks, not to replace them. ${ }^{81}$ Beyond this, Wells hoped that someone, somewhere, would design a sample school syllabus, together with an accompanying examination, so that bit by bit a Wellsian approach to history would replace existing courses of study. Once this happened, he envisaged a wave of teachers and publishers setting themselves to "abstract, improve, paraphrase, plagiarise, and adapt the Outline for class use." 82 There were undoubtedly history teachers who took inspiration from Wells's work. In the words of one Canadian teacher, writing in 1929: "It is now fairly generally accepted that the teaching of history should tend to inculcate the ideals of world peace.... Therefore, more than ever before, we need a background of world history. A one-year course in World History is not enough." 83 However, no ministry of education ever used Wells's ideas as the basis of its history curriculum. The League of Nations education experts, looking for ways to make history curricula more global in scope, occasionally considered Wells's advocacy of a single global history text to be used in all the world's schools alike but always rejected the idea as impractical on both political and educational grounds and, for some, "fundamentally fallacious." 84

After the publication of The Outline of History Wells turned to the production of two other multi-volume works designed to delineate the "informative content" of school curricula and to summarize in readable form the knowledge that all citizens should possess if they were to play their part in shaping the future: The Science of Life (4 vols., 1931) and The Work, Wealth and Happiness of Mankind (2 vols., 1931). As these titles indicate, he divided this knowledge into three components: history, science (and especially biology), and what he called human ecology, which was in effect an interdisciplinary social science resting heavily on sociology, psychology, and economics. In his view, "minds resting on that triple foundation will be equipped for the role of world citizens and I do not believe that a world community can be held together in a common understanding except upon such a foundation. ${ }^{\prime 55}$ In the $1930 \mathrm{~s}$ Wells promoted a plan for a "world encyclopedia" that would make universally available all this knowledge, though this proved to be beyond even his prodigious energy. The encyclopedia was to be a constantly up-dated compendium of knowledge with a permanently endowed staff and organizational apparatus that would set out the Wellsian view of the world and facilitate "the concentration of research and thought and the direction of the general education of mankind." 86

During the inter-war years, Wells outlined a number of generalized curriculum schemes, of which the most elaborate appeared in 1937. In it he calculated that a typical school week would contain some thirty hours that could be devoted to specific instructional purposes but that once time had been taken out for physical education, reading, mathematics, a second language, music, and so on, only six hours would be 
left for the kind of "informative content" in which he was primarily interested. Over ten years of schooling, therefore, allowing for forty weeks of schooling per year, this would amount to 2,400 hours in total. Wells divided this time into three stages: the first year or two of school; then the next four or so years; and finally the last four years. In all three stages, the "informative content" of his curriculum would consist of history, science, and human ecology, appropriately organized and sequenced.

In the first years, Wells recommended the use of stories and physical objects, all designed to show young children that they had roots in the past, that an interesting world of physical phenomena existed around them, and that there were methods of investigation they should learn so that they could examine the world for themselves. Over the next four years, between seven and eleven years of age, Wells assigned history some $40 \%$ of the available time, with the remaining $60 \%$ allotted to science and human ecology. In history students would explore the classic Wellsian themes of the origins of the earth and of life, the rise of civilizations, and the growth in the power of human beings to shape their world, all with the intent that students would think "less like gossiping court pages and more like horse-riders, seamen, artist-artisans, road-makers and city-builders, which I take it is in spirit what we want them to be." ${ }^{\prime 87}$ In the final four years, covering the ages between eleven and fifteen, students would continue to devote $40 \%$ of their time to history, though now with more of an economic and political emphasis. They would examine the history of ideologies and the rise and fall of empires, and would make a special study of the history of war. The remaining $60 \%$ of the time would be devoted to science and human ecology. After the completion of these three stages of schooling, Wells envisaged a system of compulsory part-time adult education centring upon contemporary history and world politics, the analysis of propaganda, and the pursuit of personal interests. His scheme, Wells conceded, might seem overly ambitious, but it was nonetheless necessary. This was a world that had seen "the Zeppelin, the radio, the bombing aeroplane come absolutely out of nothing since 1900 . And our schools are going along very much as they were going along thirty-seven years ago." ${ }^{88}$

Wells synthesized his arguments at a conference organized by the League of Nations Union in England in 1938 and then in a repeat performance in Australia. In the world as it existed in 1938, he argued, "the adjustment of history to reality has become a matter of supreme urgency." ${ }^{89}$ That reality included Wells's usual targets: economic crisis; the accelerating likelihood of war; the increasing destructiveness of modern weaponry; the depletion of the world's resources; nationalism and international rivalries; the failure of history teachers to address these issues; and the general sense of helplessness that seemed to grip so many people. Their version of the past, Wells told his audiences of history teachers, blinded them to what was actually happening in the world: "You see conceptions of national conquest, glory, revenges and sentimental releases, all the romantic lures of the conventional historian equipped with destructive power beyond all previous times and you do not properly realize how much this is associated with your work, how much you do in keeping alive the ideas that paralyze drastic social development and lead to war." ${ }^{\prime 0}$

In Wells's lecture one can find all his criticisms of traditional history counterposed 
against his curricular alternative. First, traditional history teaching was incurably nationalistic, and therefore inescapably divisive and often excessively bellicose, while Wellsian history was universal, and therefore unifying and pacific. Second, existing history was too heavily based on written sources, and thus inevitably became a history of events, institutions, and personalities, largely political in nature, while Wellsian history turned to biology, archaeology, and the social sciences and became a history of ideas and cultures, of long-term change and continuity. Third, its reliance on the written record meant that conventional history took too short a view of the past and therefore had an unduly restricted view of the nature of human beings, while Wellsian history went back to the very origins of the universe and gave due attention to humanity's early heritage. Fourth, traditional history put too much emphasis on the specific event and the individual personality, thereby becoming anecdotal and gossipy, while Wellsian history subordinated detail and description to the analysis of longer term developments and "operating causes." ${ }^{91}$ Fifth, traditional history was "a mass of pretentious narrative almost entirely useless for any practical purpose at all," while Wellsian history deliberately set out to be useful by illuminating the world of the present and charting a course to the future. ${ }^{92}$ Sixth, traditional history bored children and was largely unintelligible to them, while Wellsian history dealt with activities, inventions, and discoveries that could easily be made concrete and tangible and therefore pedagogically worthwhile and interesting. Seventh, traditional history said little or nothing about science, technology, communication, and transportation, not to mention such crucial factors as climate and physical environment, whereas Wellsian history treated them, and not states and nations, as central to the historical process. Eighth, traditional history dwelt far too heavily on Europe and, to a lesser extent, its post-Columbus extensions in the Americas, while Wellsian history attempted to treat all the world's regions and cultures equally.

\section{Wells as Pedagogue}

Wells said very little in detail about how his kind of history might best be taught, believing that once teachers had a clear idea of why they were teaching and were given a worthwhile curriculum to follow, the question of how to teach would largely solve itself. In general he favoured the child-centred, activity-based pedagogy promoted by the pioneers of the "new education" of the late nineteenth and early twentieth centuries. Very early in his career, in 1891, he took it as given that any subject that was taught simply as "information accumulation, without any mental exercise except that of the memory ... should be mended or ended as part of the school curriculum." 93 It is an indication of his pedagogical views that the three schoolbooks explicitly based on his Outline, all with his permission, embraced a student-centred pedagogy. Indeed, one of them carried activity-based teaching methods to extremes, suggesting, for example, that students might learn about early humans by wrapping themselves in a skin rug held together by sharpened twigs (though also adding that it might be as well to wear a bathing suit underneath) or simulating the effects of poison gas by sniffing chlorine or standing in the smoke of a bonfire. ${ }^{94}$ 
Wells was certainly no friend of traditional didacticism, and spoke favourably of such pedagogical pioneers as Pestalozzi and Froebel, though he never made any reference to the work of such contemporary American educationists as John Dewey, Harold Rugg, George Counts, or William Kilpatrick (while Dewey for his part regarded Wells as altogether too dogmatic in his diagnoses and solutions of contemporary problems). Wells was fully in favour of "cooperative laboratory inquiry" and wanted to see "rooms with desks facing a rostrum" replaced by libraries and resource centres. ${ }^{95}$ Compulsion and competition still prevailed in many schools but the day was coming, or so Wells hoped, when natural interest would be the basis for all teaching and learning. He was convinced that students found traditional history boring and that Wellsian history would almost automatically command their interest: "For growing youth there could be nothing more interesting than the evidence of slowly unfolding skill and knowledge, the first implements and the first weapons, the first fires and the earliest habitations, the beginnings of art, the supersession of the hunting and fishing life of the palaeolithic savage by the life of the Neolithic herdsman and agriculturalist." ${ }^{\prime 6}$ Men and women, young and old, were driven by an insatiable thirst for knowledge and that was something that good teachers, armed with a sensible curriculum, could use to their advantage. Knowledgeable teachers, inspired by the Wellsian vision of universal history, could not help but engage the attention of students. What mattered was not pedagogical wizardry but the teacher's personality and skill.

Wells wanted the teacher to be "the anticipator, the planner, and the foundationmaker of the new and great order of human life that arises now visibly amidst the decaying structures of the old." ${ }^{97}$ In reality, however, these decaying structures proved to be much more solid than they appeared and teachers were hemmed in by adverse working conditions, inadequate training, narrow curricula, authorized textbooks, and external examinations, all designed to maintain the pedagogical status quo and uphold the dogmas of the nation-state. The result was that teachers were "ill-trained, ill-treated, ill-organized, poorly respected and much abused," either "young and inexperienced or old and discouraged." 98 Only one-third were performing satisfactorily and even they lagged behind the times. The other two-thirds were "in urgent need of either reconditioning or superannuation." ${ }^{99}$ In these circumstances, teachers could not be expected to be a source of change. They were too "encumbered with a voluminous mass of low-grade mental toil and worries and reasonable and unreasonable responsibilities to find the energy and mental freedom necessary to make any vital changes in the methods that textbooks, traditions, and examinations force upon them." ${ }^{100}$ Teachers were not in the dock, they were "part of the array of victims."101

To correct this state of affairs Wells proposed the creation of model lessons to be broadcast via radio or film. Once this was done, all a teacher would have to do was "to spend five minutes on getting out the films he wants, ten minutes in reading over the corresponding lecture notes, and then he can run the film, give the lesson, question his class upon it, note what they miss and how they take it, run the film again for a second scrutiny, and get out for the subsequent study of the class the ample supply of diagrams and pictures needed to fix the lesson." ${ }^{102}$ A new kind of school beckoned, well equipped with apparatus and resources, and with ready access to prepackaged 
lessons, in which all around the world a uniform curriculum could be delivered: "In the place of little ill-equipped schools, each run by its own teacher and buying its own books and diagrams and material and so forth in small quantities at high prices, I want to see a great central organization, employing teachers of genius, working in consultation and co-operation and producing lesson notes, diagrams, films, phonograph records, cheaply, abundantly, on a big scale..." 103 Only in this way could one common vision of universal history be taught uniformly and efficiently to all the world's children.

Wells was not always this dogmatic, however, and a more flexible vision of history teaching can be found in his admiration for F.W. Sanderson, the reforming headmaster of Oundle School, where Wells sent his own sons and whom he described as "beyond question the greatest man I have ever known with any degree of intimacy" - high praise indeed in view of Wells's wide circle of friends and contacts. ${ }^{104}$ Wells saw in Sanderson's school a demonstration that his ideas were not as impractical as he sometimes feared, finding that "all the educational possibilities that I had hitherto felt to be unattainable dreams, matters of speculation, things a little too extravagant even to talk about in our dull age, I found being pushed far towards realisation by this bold, persistent, humorous, and most capable man." 105

Like Wells, Sanderson placed history at the heart of the curriculum and, also like Wells, he believed that "nothing less than the universality of history should be stressed," though, unlike Wells, he also ensured that his students spent considerable time on English and European history. ${ }^{106}$ Perhaps because they knew of the friendship between the two men, Sanderson's memorialists went out of their way to disassociate him from Wells's dismissal of so-called great men in history: "On the contrary, it was the honest, but as he believed mistaken, efforts of some authors to belittle such figures which he deprecated. In Alexander, Caesar, and Napoleon he saw something of that great plan which he believed it was the true function of History to reveal; he would not hear of the casual application of the title 'Adventurer' to men who, in his opinion, were but the agents or the instruments of a universal purpose." ${ }^{107}$ Presumably, this singling out of three of Wells's favourite targets — Alexander, Caesar, and Napoleon — as adventurers was not accidental and some of the contributors to Sanderson's memorial biography decided to put Wells in his place.

Sanderson rejected conventional textbook-based recitation methods of teaching and instead made the library the centre of teaching and learning. It became history's equivalent of the laboratory in science or the workshop in manual subjects. At the beginning of the school year students were given lists of books (and not textbooks or children's books but the standard adult authorities) dealing with their assigned periods of study, together with questions for discussion and investigation. They spent the first term of the school year reading and discussing their findings and then worked in small groups preparing "enquiries" as in these examples: "an Enquiry into the Fairness of the Title 'Adventurer' as applied to Napoleon in a recent historical work; an Enquiry into the Condition of the Agricultural Labourer from 1740: Reports and Charts; an Enquiry into the Responsibility of Prussia for the Disasters which overtook her in 1806-1807."108

Sanderson's most imaginative project for improving the teaching of history, and 
one that was much praised by Wells, was the construction of a "Temple of Vision" that would depict the progress of humanity from the very beginnings of time. Intended as a memorial to the graduates of Oundle who had been killed in the First World War, it was not to be a museum of static objects but "a temple to the whole human adventure," presenting a cumulative narrative, told in words, pictures, diagrams, and artefacts, that would sweep those who saw it into the movement of history and inspire in them a sense of identity with the human species as one united whole. ${ }^{109}$ As Wells described it:

It was not to have been a laboratory or a classroom, but a place to which boys whose minds were opening out from the age of thirteen or fourteen upward were to have gone to look and talk and learn. About the walls there were to have been chronological charts planned to show the ever-quickening evolution of life and mankind. In cases about the room, exhibits were designed to illustrate the steady upward thrust of human progress, exhibits showing the development of human implements, of the use of metals, of the means of locomotion, of the arts of the architect and engineer. These exhibits were to have been constantly refreshed and renewed by groups of boys ... but their message was to have remained the same. It was to have been the message of life moving onward and upward from slow, lowly, and instinctive beginnings towards conscious unity and power. All the teaching of Oundle School, and especially the historical and geographical and literary work, was to have been re-planned in relation to that Temple of Vision, and the influence of that temple was to have radiated back upon the work in the school. ${ }^{110}$

We are a long way removed here from the mechanical recording of model lessons that Wells had advocated only a year earlier but, as his use of the conditional voice indicates, the Temple of Vision was in fact never built. Sanderson had begun to plan it before his sudden death in 1922 but his successors did not continue with it.

In his 1919 novel, The Undying Fire, Wells based the central character, Job Huss, on Sanderson and his work at Oundle. Huss was a reforming headmaster whose job was in danger because his modernizing ways had offended some of the school's governing body (and because he had committed the cardinal error of taking educational theory too seriously) and Wells invented a letter of support written to Huss by one of his former history students: "You made us think and feel that we were in one living story with the reindeer men and the Egyptian priests, with the soldiers of Caesar and the alchemists of Spain; nothing was dead and nothing alien; you made discovery and civilization our adventure and the whole future our inheritance." ${ }^{111}$ It is a vision of history teaching that retains its attraction today.

\section{"Altogether Lonely and Immediately Futile"}

With the outbreak of the Second World War, Wells was forced to conclude that his twenty-year campaign to transform the teaching of history had failed. He was hailed 
on all sides as an educator but his many readers had obstinately failed to learn, or at least to act on, what he tried to teach them. The foundation of his argument was that human behaviour is the product of a deep history that stretches back into distant time and that, once this reality is understood, men and women will change how they think and act. He ignored the obvious objection that if we are in fact so heavily conditioned by such a long and deeply embedded history, then it does not necessarily follow that understanding our historical heritage will enable us to overcome it. The past might simply be too powerful. As a Canadian academic noted in 1936, "Experience is a slow teacher and we all become impatient and want to use short cuts as we try to do in our schools and universities. But I am rather sceptical about short cuts working where nations and not individuals are concerned." 112

At times Wells at time came close to admitting this possibility, consoling himself with the thought that the kinds of changes he sought might bear fruit only in a distant future, although, as he demonstrated early in his career in The Time Machine, he was also capable of presenting his readers with an extremely bleak vision of that future. In his autobiography, published in 1934, he described himself as sometimes "oppressed by the apparent lack of direct consequence to all my voluminous efforts" and compared himself to the medieval philosopher, Roger Bacon, "a man altogether lonely and immediately futile, a man lit by a vision of the world still some centuries ahead, convinced of its reality and urgency, and yet powerless to bring it nearer." 113 One of his sons, Anthony West, has argued that in his heart of hearts Wells knew that humanity was simply not capable of the effort he demanded of it, and that human society was best represented by the island of Dr. Moreau where "men of goodwill were building on sand with obdurate material which by its essence excluded any possibility of success." Thus, says West, in much of his work Wells was "engaged in shouting down his own better judgment." 114

Whatever the case, it seems clear that few people, including those who read Wells's many books and essays, were ready to cast aside the enticements of national identity and patriotism, while Wells's plans for an "open conspiracy" were too nebulously unrealistic to have any political impact. His own analysis was that teachers were too hemmed in by the "grindstone of actual lesson-giving," universities lacked any sense of "an educational duty to the community as a whole," academic educationists were too concerned with details of pedagogy and school organization, and educational policy-makers were too much part of the system to see beyond it. ${ }^{15}$ Thus, as Wells saw it, the only hope was to create an activist public opinion that would promote the changes he saw as so necessary. All of which meant, as Wells concluded in his more pessimistic moments, that education was all too likely to lose its race with catastrophe.

Even so, his educational ideas retain a certain interest, especially for anyone involved with history education in the schools. Few people have invested such high hopes in the teaching of history as did Wells. For him, history was not simply a subject in the curriculum; it was "the core of initiation" into what it means to be both a human being and a citizen of the world. ${ }^{116}$ As he wrote in 1921, "To-day if life seems adventurous and fragmentary and generally aimless it is largely because ... 
we have lost touch with History. We have ceased to see human affairs as one great epic unfolding. And only by the universal teaching of Universal History can that epic quality be restored." 117 Wells's hopes for a reformed history education can be variously dismissed as utopian, dogmatic, or misguided but they constitute a noteworthy, albeit largely forgotten, chapter in the history of history education. As in the years after the First World War, the teaching of history has once again become a subject of increasing professional, public, and even political debate that touches on many of Wells's preoccupations, as the ongoing "history wars" continue to demonstrate around the world. National history curricula and national history standards are regularly formulated and just as regularly contested. History textbooks have come under continuing scrutiny. Around the world there are signs that history curricula are becoming more international in scope, whether by incorporating courses in world history or through the study of global issues, changing from "a solely national focus to one in which world issues and international organizations are also emphasized." 118 At the same time, the role of history in educating for national and global citizenship and strengthening national and global identities is much discussed, as is the striking of an appropriate balance between factual knowledge and historical thinking. ${ }^{119}$ As yet, however, there are no signs that a Wellsian approach to history education has attracted much if any attention, though it is perhaps not too far-fetched to see Wells as a distant precursor of what today we are learning to call "big history" and of the kind of world history being pioneered by the Advancement Placement programme in high schools. ${ }^{120}$ It might even be that his vision of a reformed history education has gained a new relevancy in today's nuclear-armed and globalizing world with its propensity for inter-state and intra-state violence, its environmental and other crises, and its declining levels of civic engagement. There is something eerily prescient in his 1937 comment that homo sapiens was doing nothing to guard against the prospect that "In quite a little while now, in a few decades at most, it will be possible for any small body of desperate men to poison your whole atmosphere, sweep your world bare with infections, or blow your planet to pieces." 121

Wells would have agreed with today's history educators that the ability to think historically is important but would also have insisted that historical thinking must be part of a wider vision of history teaching as serving a social purpose - in Wells's case a minimalist commitment to avoiding social catastrophe and a maximalist commitment to shaping what he saw as a saner future. Thus, the ability to think historically had to go hand in hand with the possession of a prescribed body of historical knowledge and, as we have seen, Wells had a clear idea of just what that knowledge should be if the teaching of history was to serve a truly educational purpose: "There can be no peace now, we realize, but a common peace in all the world; no prosperity but a general prosperity. But there can be no common peace without common historical ideas.... A sense of history as the common adventure of all mankind is as necessary for peace within as it is for peace between the nations." 122

As he wrote shortly after the First World War, "This is a world where folly and hate can bawl sanity out of hearing. Only the determination of schoolmasters and teachers can hope to change that. How can you hope to change it by anything but 
teaching? Cannot you realize what teaching means?" ${ }^{123}$ Most people apparently could not. Towards the end of the Second World War, when asked what he thought would be an appropriate epitaph on his grave, Wells replied "God-damn you all, I told you so." 124

\section{Notes}

1 H.G. Wells, The Salvaging of Civilization (New York: Macmillan, 1921), 153.

2 H.G. Wells, The Work, Wealth and Happiness of Mankind (New York: Doubleday Moran, 1931), Vol.2, 818.

3 H.G. Wells, World Brain (London: Watts, 1938), 110-111.

4 The Times Literary Supplement, 17 August, 1946: 391. For similar tributes, see George Orwell, "Wells, Hitler and the World State," in Sonia Orwell \& Ian Angus (eds.), The Collected Essays, Journalism and Letters of George Orwell, Vol. 2, My Country Right or Left, 1940-1943 (London: Secker \& Warburg, 1968), 143; The New York Times, 14 August, 1946: 24; Sinclair Lewis, "A Generation Nourished on H.G. Wells" in New York Herald Tribune, 20 October, 1926: book review section.

5 David Fromkin, Europe's Last Summer: Who Started the Great War in 1914? (New York: Knopf, 2004), 8. For an argument that the impact of the War on British society might have been overstated over the years, see David Reynolds, The Long Shadow: The Great War and the Twentieth Century (New York: Simon \& Schuster, 2013).

6 Documents on Canadian External Relations, Vol. 2: The Paris Peace Conference of 1919 (Ottawa: Department of External Affairs, 1969), 49.

7 "The Effect of the War on the Teaching of History: III, Discussion at the Annual Meeting," History 3, 9 (April 1918): 20.

8 Frederick J. Gould, British Education after the War (London: Watts, 1917), 5.

9 Report of the Proceedings of the National Conference of Character Education in Relation to Citizenship, Board of Trade Building, Winnipeg, October 20-22, 1919, 6

10 James H. Putnam \& George M. Weir, Survey of the School System (Victoria, BC: King's Printer, 1925), 57.

11 For examples of the extensive interwar literature on history teaching, see Helen Madeley, History as a School of Citizenship (London: Oxford University Press, 1920); J.C. Garnet, Education and World Citizenship: Towards a Science of Education (Cambridge: Cambridge University Press, 1921); Frederick J. Gould, History the Teacher: Education Inspired by Humanity's Story (London: Methuen, 1921); Charles N. Cochrane \& William S. Milner, Observations on the Teaching of History and Civics in Primary and Secondary Schools of Canada (Winnipeg: National Council of Education, 1923); Jonathan F. Scott, The Menace of Nationalism in Education (London: Allen \& Unwin, 1926); Carnegie Endowment for International Peace, Enquête sur les livres scolaires d'après-guerre (Paris: CEIP, 1923/26); William H. Kilpatrick, Education for a Changing World (New York: Macmillan, 1926); William G. Carr, Education for World Citizenship (Stanford: Stanford University Press, 1928); Fred Clarke, Foundations of History Teaching (Oxford: Oxford University Press, 1929); Harriet A. Drummond, The Teaching of History in Schools: A Study of Some of its Problems (London: Harrap, 1929); Harold Rugg, Man and His Changing Society (Boston: Ginn, 1929); JeanJacques Clarapède, L'enseignement de l'histoire et l'esprit international (Paris: Les Presses Universitaires de France, 1931); Lorne Pierce, New History for Old: Discussions on Aims and Methods in Writing and Teaching History (Toronto: Ryerson, 1931); International Institute of Intellectual Cooperation, Textbook Revision and International Understanding (Paris: IIIC, 1933); Spencer Stoker, The Schools and International Understanding (Chapel 
Hill: University of North Carolina Press, 1933); American Historical Association, Report of the Commission on Social Studies: Conclusions and Recommendations (New York: Scribners, 1934); Frederick R. Worts, The Teaching of History in Schools: A New Approach (London: Heinemann, 1935); Ernest Simon \& Eva Hubback, Training in Citizenship (London: Oxford University Press, 1935).

12 Frederick J. Gould, British Education after the War (London: Watts, 1917), 1. See also Bertrand Russell, Principles of Social Reconstruction (London: Allen \& Unwin, 1916) and, for a modern history, Paul B. Johnson, Land Fit for Heroes: The Planning of British Reconstruction 1916-1919 (Chicago: University of Chicago Press, 1968).

13 Alfred E. Zimmern, "Education for World Citizenship" in Problems of Peace, 5th Series: Lectures Delivered at the Geneva Institute of International Relations August 1930 (reprinted edn., Freeport: Books for Libraries Press, 1970), 313.

14 The Times, 13 September, 1918, cited in Harry Judge, "H.A.L. Fisher: Scholar and Minister," Oxford Review of Education, 32, 1 (February 2006): 9.

15 "The Effect of the War on the Teaching of History: III, Discussion at the Annual Meeting," History 3, 9 (April 1918): 22.

16 H.G. Wells, Mankind in the Making (London: Chapman \& Hall, 1903), 222.

17 H.G. Wells, What Are We to Do with Our Lives? (London: Watts, 1929), 18.

18 H.G. Wells, The Outline of History (New York: Macmillan, 1926), 1. Successive editions of the Outline vary in detail, so that the date of publication should always be taken into account. Florence Deeks of Toronto accused Wells of plagiarizing a manuscript she had written and pursued him through the courts throughout the 1920s until her case was finally dismissed. See A. Brian McKillop, The Spinster and the Prophet: Florence Deeks, H.G. Wells, and the Mystery of the Purloined Plot (Toronto: Macfarlane, Walter and Ross, 2000).

19 H.G. Wells, Experiment in Autobiography (New York: Macmillan, 1934), 612-613.

20 H.G. Wells, The Outline of History (New York: Macmillan, 1926), 4.

21 H.G. Wells, "The Traveller Provokes his Old Friends, the Teachers, Again in a Paper Called "The Poison Called History," in his Travels of a Republican Radical in Search of Hot Water (Harmondsworth: Penguin, 1939), 89-121.

22 H.G. Wells, The War that Will End War (London, Palmer 1914).

23 H.G. Wells, The World of William Clissold (New York: Doran, 1926), 627-8.

24 H.G. Wells, What Are We To Do with Our Lives? (London: Watts, 1935), 78.

25 H.G. Wells, The Wonderful Visit (London: Dent Wayfarers Library, n.d.), 143-144.

26 H.G. Wells, The Outline of History (New York: Macmillan, 1920), Vol. 2, 583. Italics are in the original.

27 H.G. Wells, The Salvaging of Civilization (New York: Macmillan, 1921), 39.

28 David C. Smith, H.G. Wells: Desperately Mortal (New Haven: Yale University Press, 1986), 258.

29 H.G. Wells, Experiment in Autobiography (New York: Macmillan, 1934), 615.

30 Paul Klappen, The Teaching of History (New York: Appleton, 1926), 182ff.

31 H.G. Wells, The World of William Clissold (New York: Doran, 1926), 890 and Travels of a Radical Republican in Search of Hot Water (Harmondsworth: Penguin, 1939), 91.

32 John R. Hammond, H.G. Wells and Rebecca West (London: St. Martin's Press, 1991), 119.

33 Cited in W. W. Wagar, H.G. Wells and the World State (New Haven: Yale University Press, 1961), 147n.

34 Ibid., 78 \& 151.

35 Memoranda for the Guidance of Teachers in the Protestant Schools of the Province of Quebec (Quebec: Council of Public Instruction, 1934), 25.

36 H.G. Wells, After Democracy: Addresses and Papers on the Present World Situation (London: Watts, 1932), 102. 
37 The "squirming heap" quotation comes from H.G. Wells, Travels of a Republican Radical in Search of Hot Water (Harmondsworth: Penguin, 1939), 121.

38 Letter to The Times, October 1, 1936, quoted in David C. Smith (ed.), The Correspondence of H.G. Wells, Volume 4 (London: Pickering \& Chatto, 1998): 96. See also Wells's dismissive comments on the Committee in his The Work, Wealth and Happiness of Mankind (Garden City NY: Doubleday, 1931), Vol. 2, 700-703.

39 H.G. Wells, Experiment in Autobiography (New York: Macmillan., 1934), 658.

40 Ibid., 670.

41 H.G. Wells, Travels of a Republican Radical in Search of Hot Water (Harmondsworth: Penguin, 1939), 93.

42 H.G. Wells, Experiment in Autobiography (New York: Macmillan, 1934), 658.

43 Wells to Marie Butts, Wells Papers at the University of Illinois, Champaign-Urbana, File WB 91-9, 19 September, 1919.

44 H.G. Wells, Experiment in Autobiography (New York: Macmillan, 1934), 630.

45 H.G. Wells, The Work, Wealth and Happiness of Mankind (New York: Doubleday Doran, 1931), Vol. 1, 13. For Wells's own spoof of his interpretation of history, see his The Camford Visitation (London: Methuen, 1937), 37-38.

46 Winwood Reade, The Martyrdom of Man (London: Kegan Paul, Trench, Trubner, 1892 edn.). On the new history, see James Harvey Robinson, The New History (New York: Macmillan, 1912). Also relevant are James H. Robinson, The Mind in the Making (New York: Harper, 1921) and James H. Breasted, The Dawn of Conscience (New York: Scribners, 1933).

47 H.G. Wells, World Brain (London: Watts, 1938), 8.

48 H.G. Wells, The Camford Visitation (London: Methuen, 1937), 36.

49 H.G. Wells, The Commonsense of War and Peace: World Revolution or War Unending (Harmondsworth: Penguin, 1940), 7.

50 H.G. Wells, Experiment in Autobiography (New York: Macmillan, 1934), 11.

51 H.G. Wells, The World of William Clissold (New York: Doran, 1926), 212.

52 Wells to the editor of The Listener, 30 March, 1942, cited in David C. Smith (ed.), The Correspondence of H.G. Wells, Vol. 4, 1935-1946 (London: Pickering \& Chatto, 1998), 326.

53 H.G. Wells, In the Fourth Year (New York: Macmillan, 1918), 99; and "The Traveller Provokes his Old Friends, the Teachers, again in a Paper called 'The Poison Called History" in his Travels of a Republican Radical in Search of Hot Water (Harmondsworth: Penguin, 1939), 108.

54 H.G. Wells, Travels of a Republican Radical in Search of Hot Water (Harmondsworth: Penguin, 1939), 110.

55 H.G. Wells, The New World Order (New York: Knopf, 1940), 23.

56 H.G. Wells, Travels of a Republican Radical in Search of Hot Water (Harmondsworth: Penguin, 1939), 111.

57 H.G. Wells, Men like Gods (Toronto: Macmillan, 1923), 80. The italics are in the original.

58 H.G. Wells, Phoenix: A Summary of the Inescapable Conditions of World Reorganization (London: Secker \& Warburg, 1942), 182

59 H.G. Wells, What Are We to Do with Our Lives? (London: Watts, 1935), 57.

60 Arthur Salter, Personality in Politics (London: Faber \& Faber, 1947 ), 123.

61 H.G. Wells, Washington and the Riddle of Peace (New York: Macmillan, 1922), 205.

62 Ibid., 205.

63 H.G. Wells, New Worlds for Old (New York: Macmillan, 1907), 241.

64 Ibid., 237.

65 H.G. Wells, World Brain (London: Watts, 1938), xvi.

66 H.G. Wells, "Morals and Civilisation," Fortnightly Review, 61 (February, 1897), 268. 
67 H.G. Wells, What Are We to Do with Our Lives? (London: Watts, 1935), 113; H.G. Wells, The Open Conspiracy: Blueprint for a World Revolution (New York: Doubleday Doran, 1928).

68 H.G. Wells, "History for Everybody: A Postscript to The Outline of History," Fortnightly Review, 1 June, 1921: 888-889.

69 H.G. Wells, Mankind in the Making (London: Chapman \& Hall, 1903), 210.

70 H.G. Wells, "History for Everybody: A Postscript to The Outline of History," Fortnightly Review, 1 June, 1921: 889.

71 Ibid., 888.

72 H.G. Wells, The Camford Visitation (London: Methuen, 1937), 64.

73 H.G. Wells, Mr. Belloc Objects to the "Outline of History" (London: Watts, 1926), 51.

74 Carl Becker, "Mr. Wells and the New History" in his Everyman his own Historian (New York: Crofts, 1935), 185. The review first appeared in the American Historical Review, 26 (1921): 641-6.

75 A.M.P., “The Dawn," The Manitoba Teacher, January, 1926: 10.

76 A. J. Grant reviewing The Outline of History in History, 5, No. 20 (1921): 215.

77 H.G. Wells, The Outline of History (New York: Macmillan, 1920), Vol. 1, 399.

78 Ibid., 397, 399-400.

79 Ibid., 6.

80 H.G. Wells, The Work, Wealth and Happiness of Mankind (New York: Doubleday Doran, 1931), Vol. 2, 835. All the quotations in this paragraph are from pp. 835-6 of this work.

81 Edward H. Carter, A Short History of Mankind by H.G. Wells (Oxford: Blackwell, 1925); Ifor O. Evans, Suggestions for Practical Work in World History (London: World Service Series \#1, 1929); and Ifor O. Evans, The Junior Outline of History (London: Denis Archer, 1932). Wells gave his permission for all three books but did not involve himself personally with their preparation or use.

82 H.G. Wells, "A Postscript to The Outline of History," Fortnightly Review, 1 June, 1921: 910.

83 "Some Comments on the Proposed Courses in History," Manitoba Teacher (April, 1929): 18.

84 Alfred E. Zimmern, Learning and Leadership: A Study of the Needs and Possibilities of International and Intellectual Organization (London: Oxford University Press, 1928), 34. On the League of Nations and history education see Pham Thi Tu, La Coopération Intellectuelle sous la Société des Nations (Geneva: Librairie E. Droz, 1962); Jean-Jacques Renoliet, L'UNESCO oublié: La Société des Nations et la coopération intellectuelle 1919-1946 (Paris: Publications de la Sorbonne, 1999).

85 H.G. Wells, Experiment in Autobiography (New York: Macmillan, 1934), 618-619.

86 H.G. Wells, The Work, Wealth, and Happiness of Mankind (New York: Doubleday Doran, 1931), Vol.2, 846. For more on Wells' encyclopedia project, see his World Brain (London: Watts, 1938).

87 H.G. Wells, World Brain (London: Watts, 1938), 113. Wells's curriculum plan is described on pp. 97-130.

88 Ibid., (London: Watts, 1938), 129.

89 H.G. Wells, "The Traveller Provokes his Old Friends, the Teachers, Again in a Paper Called "The Poison Called History," in his Travels of Republican Radical in Search of Hot Water (Harmondsworth: Penguin, 1939), 90.

90 Ibid., 90.

91 Ibid., 94.

92 Ibid., 96 \&109.

93 Wells to the Editor, The Educational Times, August, 1991, quoted in David C. Smith (ed.), The Correspondence of H.G. Wells, Vol. 1, 1880-1903 (London: Pickering \& Chatto, 1998), 170. 
94 Ifor O. Evans, Suggestions for Practical Work in World History (London: World Service Series, 1929), $14 \& 50$.

95 Wells writing in 1941, quoted in David C. Smith (ed.), The Correspondence of H.G. Wells, Vol.4, 1935-1946 (London: Pickering \& Chatto, 1998), 314.

96 H.G. Wells, History Is One (Boston: Ginn, 1919), 6.

97 H.G. Wells, The Story of a Great Schoolmaster (New York: Macmillan, 1924), 8-9.

98 H.G. Wells, Mankind in the Making (London: Chapman \& Hall, 1903), 143-144; and World Brain (London: Watts, 1938), 117.

99 H.G. Wells, World Brain (London: Watts, 1938), 135.

100 H.G. Wells, Mankind in the Making (London: Chapman and Hall, 1903), 222.

101 D.C. Smith (ed.), The Correspondence of H.G. Wells (London: Pickering \& Chatto, 1998), Vol. 3: 7.

102 H.G. Wells, The Salvaging of Civilization (New York: Macmillan, 1931), 164.

103 Ibid., 165-166.

104 H.G. Wells, The Story of a Great Schoolmaster (New York: Macmillan, 1924), 1. Sanderson died unexpectedly while giving a speech in 1922 and with Wells sharing the stage. Disappointed by a memorial volume that Sanderson's colleagues prepared, Wells decided to write his own personal tribute, even though in the process he offended Sanderson's widow by airing incidents she would have preferred to remain forgotten. The memorial volume that Wells found wanting was Sanderson of Oundle (New York: Macmillan, 1924). The book was prepared by an editorial committee under Wells's editorial guidance and no specific authors were named. For another description of history teaching at Oundle, see J.A. Higgs Walker, "The Teaching of History in Schools: IV, Oundle," History, 10 (\#39) (1925): 234-239.

105 H.G. Wells, The Story of a Great Schoolmaster (New York: Macmillan, 1924), 4.

106 Sanderson of Oundle (New York: Macmillan, 1924), 130.

107 Ibid., 132-133.

108 Ibid., 126.

109 H.G. Wells, The Story of a Great Schoolmaster (New York: Macmillan, 1924), 134.

110 H.G. Wells, "What Everyone Should Learn at School," John o' London's Weekly, 13 October, 1923: 14. See also his Story of a Great Schoolmaster (New York: Macmillan), $131 f f$.

111 H.G. Wells, The Undying Fire (New York: Macmillan, 1919), 221-222.

112 Harry F. Angus, "A Policy of World-wide Cooperation?" in Interdependence, 1 \& 2 (1936): 44. Interdependence was the magazine of the League of Nations Society in Canada.

113 H.G. Wells, Experiment in Autobiography (New York: Macmillan, 1934), 623.

114 Anthony West, Principles and Persuasions (London: Eyre \& Spottiswoode, 1958), 14.

115 H.G. Wells, The New Teaching of History (London: Cassell, 1921), 7.

116 H.G. Wells, World Brain (London: Watts, 1938), 141-2.

117 H.G. Wells, The Salvaging of Civilization (New York: Macmillan, 1921), 111-112.

118 George Krüchen and Gili Drori (eds.), World Society: The Writings of John Meyer (New York: Oxford University Press, 2009), 213, drawing on Mary Raumer, The WorldWide Globalization of Civics Education Topics 1955-1995 (Stanford University Ph.D. dissertation, 1998).

119 The literature dealing with these questions is too vast to be referenced here. For international surveys of recent work in history education see Peter N. Stearns, Peter Seixas \& Sam Wineburg (eds.), Knowing Teaching and Leaning History: National and International Perspectives (New York: New York University Press, 2000); Stuart J. Foster \& Keith A. Crawford (eds.), What Shall We Tell the Children? International Perspectives on School History Textbooks (Charlotte NC: Information Age Publishing, 2006); Irene Nakou \& Isabel Barca (eds.), Contemporary Debates over History Education (Charlotte 
NC: Information Age Publishing, 2010); Tony Taylor \& Robert Guyver (eds.), History Wars and the Classroom: Global Perspectives (Charlotte NC: Information Age Publishing, 2012).

120 On "big history" see David Christian, "The Case for Big History," Journal of World History, 2 (1991): 223-238; and his Maps of Time: An Introduction to Big History (Berkeley: University of California Press, 2011). Also relevant is Fred Spier, The Structure of Big History: From the Big Bang until Today (Amsterdam: University of Amsterdam Press, 1996) and Cynthia Stokes Brown, Big History: From the Big Bang to the Present (New York: The New Press, 2012). On recent approaches to world history, see Ross E. Dunn, "The Two World Histories" in Linda Simcox \& Arie Wilschut (eds.) National History Standards: The Problems of the Canon and the Future of Teaching History (Charlotte NC: Information Age Publishing, 2009), 55-69.

121 H.G. Wells, The Camford Visitation (London: Methuen, 1937), 66.

122 H.G. Wells, The Outline of History (New York: Macmillan, 1920), Vol. 1, p.6 \& Vol. 2, p. 90.

123 H.G. Wells, The Undying Fire (New York: Macmillan, 1919), 183.

124 Ernest Barker, Age and Youth (Oxford: Oxford University Press, 1953), 108. A different version appears in the preface to the 1941 reprint of Wells's 1908 War in the Air. "I told you so. You damned fools." 